\title{
Hospitalization costs of severe bacterial pneumonia in children: comparative analysis considering different costing methods
}

\author{
Custos hospitalares de pneumonia bacteriana grave em crianças: \\ análise comparativa por diferentes métodos de custeio
}

\begin{abstract}
Sheila Elke Araujo Nunes ${ }^{1,2}$, Ruth Minamisava ${ }^{2}$, Maria Aparecida da Silva Vieira ${ }^{3}$, Alexander Itria ${ }^{2}$, Vicente Porfirio Pessoa Junior ${ }^{4}$, Ana Lúcia Sampaio Sgambatti de Andrade ${ }^{2}$, Cristiana Maria Toscano ${ }^{2}$
\end{abstract}

\begin{abstract}
Objective: To determine and compare hospitalization costs of bacterial community-acquired pneumonia cases via different costing methods under the Brazilian Public Unified Health System perspective. Methods: Cost-of-illness study based on primary data collected from a sample of 59 children aged between 28 days and 35 months and hospitalized due to bacterial pneumonia. Direct medical and non-medical costs were considered and three costing methods employed: micro-costing based on medical record review, micro-costing based on therapeutic guidelines and gross-costing based on the Brazilian Public Unified Health System reimbursement rates. Costs estimates obtained via different methods were compared using the Friedman test. Results: Cost estimates of inpatient cases of severe pneumonia amounted to $\mathrm{R} \$ 780,70 / \$$ Int. 858.7 (medical record review), $R \$ 641,90 / \$$ Int. 706.90 (therapeutic guidelines) and R\$ 594,80/\$Int. 654.28 (Brazilian Public Unified Health System reimbursement rates). Costs estimated via micro-costing (medical record review or therapeutic guidelines) did not differ significantly $(p=0.405)$, while estimates based on reimbursement rates were significantly lower compared to estimates based on therapeutic guidelines $(p<0.001)$ or record review $(p=0.006)$. Conclusion: Brazilian Public Unified Health System costs estimated via different costing methods differ significantly, with gross-costing yielding lower cost estimates. Given costs estimated by different micro-costing methods are similar and costing methods based on therapeutic guidelines are easier to apply and less expensive, this method may
\end{abstract}

be a valuable alternative for estimation of hospitalization costs of bacterial community-acquired pneumonia in children.

Keywords: Pneumonia; Hospitalization; Child; Costs and cost analysis; Health expenditures; Medical records; Unified Health System

\section{RESUMO}

Objetivo: Determinar e comparar custos hospitalares no tratamento da pneumonia bacteriana adquirida na comunidade por diferentes metodologias de custeio, na perspectiva do Sistema Único de Saúde. Métodos: Estudo de custo, com coleta de dados primários de uma amostra de 59 crianças com 28 dias a 35 meses de idade hospitalizadas por pneumonia bacteriana. Foram considerados custos diretos médicos e não médicos. Três metodologias de custeio foram utilizadas: microcusteio por revisão de prontuários, microcusteio considerando diretriz terapêutica e macrocusteio por ressarcimento do Sistema Único de Saúde. Os custos estimados pelas diferentes metodologias foram comparados utilizando o teste de Friedman. Resultados: 0s custos hospitalares de crianças com pneumonia grave foram $\mathrm{R} \$ 780,70$ (\$Int. 858.7) por revisão de prontuários, $\mathrm{R} \$ 641,90$ (\$nt. 706.90) por diretriz terapêutica e $\mathrm{R} \$ 594,80$ (\$Int. 654.28) por ressarcimento do Sistema Único de Saúde, respectivamente. A utilização de metodologias de microcusteio (revisão de prontuários e diretriz) resultou em estimativas de custos equivalentes $(p=0,405)$, enquanto 0 custo estimado por ressarcimento foi significativamente

\footnotetext{
Universidade Estadual da Região Tocantina do Maranhão, Imperatriz, MA, Brazil.

2 Universidade Federal de Goiás, Goiânia, GO, Brazil.

${ }^{3}$ Pontifícia Universidade Católica de Goiás, Goiânia, GO, Brazil.

${ }^{4}$ Hospital da Criança, Goiânia, GO, Brazil.

Corresponding author: Sheila Elke Araujo Nunes - Rua Godofredo Viana, 1,300 - Zip code: 65901-480 - Imperatriz, MA, Brazil - Phone: (55 99) 3524-2690 - E-mail: nunesearaujo@uol.com.br Received on: Oct 16, 2016 - Accepted on: Apr 7, 2017
}

Conflict of interest: The authors Ruth Minamisava and Ana Lúcia Sampaio Sgambatti de Andrade received from GlaxoSmithKline Brasil, financial aid for the population-based project cited on the methodology of this article.

DOI: 10.1590/S1679-45082017GS3855 
menor do que aqueles estimados por diretriz $(p<0,001)$ e por revisão de prontuário $(p=0,006)$, sendo, assim, significativamente diferentes. Conclusão: Na perspectiva do Sistema Único de Saúde, existe diferença significativa nos custos estimados quando se utilizam diferentes metodologias, sendo a estimativa por ressarcimento a que resulta em valores menores. Considerando que não há diferença nos valores de custos estimados por diferentes metodologias de microcusteio, a metodologia de custeio por diretriz, de mais fácil e rápida execução, é uma alternativa válida para estimativa de custos de hospitalização por pneumonias bacterianas em crianças.

Descritores: Pneumonia; Hospitalização; Criança; Custos e análise de custo; Gastos em saúde; Registros médicos; Sistema Único de Saúde

\section{INTRODUCTION}

Pneumonia is a significant cause of morbidity and mortality all over the world. In 2010, an estimated 120 million new episodes of the disease affected children aged under 5 years, with 935 thousand cases progressing to death worldwide. ${ }^{(1)}$ In Latin America, 980 thousand to 1.5 million cases of pneumonia are estimated to occur in children aged under 5 years each year. ${ }^{(2-4)}$ Brazil is one of the countries with high incidence of pneumonia worldwide. ${ }^{(5)}$

Estimated costs of inpatient treatment of pneumonia in children aged less than 5 years in Latin America range from US\$ 804.46 to US\$ $1,076.89 .^{(2,6)}$ Several costing methods with different levels of accuracy and quality may be applied to estimate disease costs, bottom-up micro-costing, top-down micro-costing and gross-costing being the most common. ${ }^{(7)}$

Pneumonia represents a high economic burden to society and the health care system. ${ }^{(2,8)}$ The Brazilian Public Unified Health System (SUS - Sistema Único de Saúde) covers about $75 \%$ of the population; therefore, estimating pediatric pneumonia costs under the SUS perspective is important. Given the variability of results across costing methods, estimation of Brazilian costs of inpatient cases of severe pneumonia in children via different methods is of particular relevance.

\section{OBJECTIVE}

To determine and compare Sistema Único de Saúde hospital costs to treat bacterial community-acquired pneumonia cases estimated via different costing methods.

\section{METHODS}

\section{Study design, location and period}

An observational descriptive partial economic evaluation study under the SUS perspective. Costs of the disease were estimated using different methods. Costing studies were carried out in Goiânia (GO) between October and December 2011.

\section{Study population and sample}

The study population comprised children aged between 28 days and 35 months hospitalized due to community-acquired pneumonia (CAP), and enrolled in a prospective population-based pneumonia surveillance study conducted in 17 child hospitals in the city of Goiânia (GO). ${ }^{(8)}$ This costing study was based on a sample of children admitted to two of these hospitals, totaling up 111 clinical beds and 38 pediatric intensive care unit (ICU) beds, accounting to approximately $30 \%$ of children hospitalized due to CAP, in a prospective population-based design. Selected cases corresponded to children hospitalized due to suspected pneumonia (cough and/or dyspnea) with clinical or radiological confirmation and receiving antimicrobial therapy during the period of admission. Cases with a discharge diagnosis of viral pneumonia, bronchiolitis, asthma or atypical pneumonia, as well as those involving patients admitted through health insurance plans were excluded.

Over the course of the study period, 1,520 children with suspected pneumonia were identified via the surveillance study, 330 of which met CAP definition criteria. Of these, $106(32 \%)$ were admitted to the two hospitals included in this study, of which 11 $(10 \%)$ were excluded due to missing records. Out of 95 children whose medical records were evaluated, $11(12 \%)$ were excluded due to lack of antimicrobial therapy over the course of hospital stay, 5 (5\%) due to diagnosis upon discharge of viral pneumonia, bronchiolitis, asthma or atypical pneumonia, and $31(31 \%)$ due to admission costs paid by a health insurance plan. The final sample comprised 59 cases of children with pneumonia and admitted through the SUS, in that, 52 children considered severe cases and treated in inpatient units, and 7 graded as very severe and treated at ICU.

\section{Cost components}

In compliance with international recommendations, ${ }^{(7,9,10)}$ direct costs were considered, including medical and non-medical costs used in previous published studies on pneumonia costs..$^{(2,10-12)}$ Medical costs included hospital services (admission to ward and/or ICU), professional services (medical fees), drugs, radiological 
examinations and laboratory tests, and respiratory physical therapy. Non-medical costs comprised daily companion charge rates. Data concerning healthcare resource utilization were analyzed from date of admission to date of discharge.

Costs were calculated in reals ( $\mathrm{R} \$$; December 2011) and converted to international dollars (\$Int.) at the rate of $\mathrm{R} \$$ (Real) 1,00=\$Int. 1.10; 2011 exchange rates). ${ }^{(13)}$

\section{Costing methods}

Three costing methods were used in this study: (1) bottom-up micro-costing (cost estimation based on medical record review); (2) top-down micro-costing, (cost estimation based on therapeutic guidelines); and (3) top-down gross-costing (cost estimation based on SUS reimbursements rates to hospital service providers).

For costing purposes, inpatient ward and ICU length of stay were taken into account in cases of very severe pneumonia treated at both levels. Procedures not listed in SUS reimbursement tables and which therefore did not have a predefined reimbursement rate (e.g., suction, nebulization and oxygen supply) were not taken into account.

\section{Costing based on medical record review}

Data concerning healthcare resource utilization were extracted from medical records. Medical costs included hospital services, medical fees, drugs and procedures; non-medical costs corresponded to daily companion charge rates (SUS charge rate, $\mathrm{R} \$ 8,00$ ).

Unitary prices of individual resources consumed were multiplied by the estimated amount of resources. Drug costs per child were calculated according to prescribed doses administered over the curse of hospital stay. Drug prices were based on average prices listed in Banco de Preços em Saúde (BPS), ${ }^{(14)}$ Câmara de Regulação do Mercado de Medicamentos (CMED) ${ }^{(15)}$ and Revista ABC Farma. ${ }^{(16)}$ Prices of similar drugs manufactured by different pharmaceutical industries vary; therefore, drug prices in this study were based on the formulary of one of the hospitals considered, and the 17\% Goiás State tax (Imposto sobre Circulação de Mercadorias e Serviços - ICMS) was calculated.

Costs of professional and hospital services, respiratory physical therapy, radiological examinations and laboratory tests were estimated based on Sistema de
Gerenciamento da Tabela de Procedimentos, Medicamentos, Órteses, Próteses e Materiais Especiais do SUS (SIGTAP), ${ }^{(17)}$ or "SUS table".

Daily hospital bed rates and medical fees were estimated by dividing respective SUS reimbursement rates by patient average length of stay.

\section{Costing based on therapeutic guidelines}

Costs of health resources consumed per patient were estimated according to standard therapeutic guidelines given by the Sociedade Brasileira de Pneumologia $e$ Tisiologia and Sociedade Brasileira de Pediatria for treatment of children hospitalized due to $\mathrm{CAP}^{(18)}$ (Chart 1).

Chart 1. Health resources considered for therapeutic-guideline-based costing of community-acquired pneumonia

\begin{tabular}{|c|c|}
\hline Components & Health resources \\
\hline \multirow[t]{2}{*}{ Drugs* } & $\begin{array}{l}\text { Children }<2 \text { months: ampicillin (50mg/kg/day) }+ \\
\text { gentamicin }(7,5 \mathrm{mg} / \mathrm{kg} / \text { day) and injectable dipyrone } \\
\text { Children } \geq 2 \text { months: crystalline penicillin } \\
(50,000 \mathrm{IU} / \mathrm{kg} / \text { day }) \text { and injectable dipyrone }\end{array}$ \\
\hline & $\begin{array}{c}\text { Very severe pneumonia: ceftriaxone (50mg/kg/day) + } \\
\text { oxacillin (50mg/kg/day) and injectable dipyrone }\end{array}$ \\
\hline Radiological examinations & 1 chest radiography \\
\hline
\end{tabular}

The length of stay at ward or ICU was the mean hospitalization days reported in selected records. As with medical record review based costing, daily hospital bed and medical fee costs were estimated by dividing respective SUS reimbursement rates by patient mean length of stay.

Drug prices listed by the national agencies BPS, ${ }^{(14)}$ CMED $^{(15)}$ and Associação Brasileira do Comércio Farmacêutico (ABC Farma) were used. ${ }^{(16)}$ The remaining components were priced according to SIGTAP. ${ }^{(17)}$ Respiratory physical therapy was not included in therapeutic guidelines. As mentioned, oxygen supply, although recommended for hypoxemic children, was not listed in SUS tables and was therefore not considered.

\section{Costing based on reimbursement rates}

Hospitalization rates practiced by SUS hospitals, or by private hospitals with contract with the SUS, are reimbursed via a package of professional and hospital services including meals, hospital room rates, 
hospital materials, drugs and ancillary diagnostic tests. This package has a fixed value defined according to diagnosis of each admission (based on ICD code indicated as diagnosis upon discharge of each patient). Reimbursement rates correspond to R $\$ 504,07 /$ Int. 554.47 (hospitalization due to pneumonia) and R\$ 78,40/\$Int. 86.24 (medical fees per hospitalization). A standard value reflecting minimum length of stay for a given diagnosis is paid. ${ }^{(19)}$ This amount is paid whenever a minimum of $50 \%$ of expected length of stay is actually completed (4 days for pneumonias cases; procedure 0303140151 - SIGTAP/DATASUS). Additional R \$20,00 are paid for longer hospitalization time (from 9 days on). ${ }^{(17,19)}$

Copies of authorizations for hospital admission (AIH - Autorizações de Internação Hospitalar) were obtained from the Hospital Information System (SIH - Sistema de Informação Hospitalar) of SUS Information Technology Department (DATASUS - Departamento de Informática do Sistema Único de Saúde) via the Municipal Health Department of Goiânia. Sistema Único de Saúde reimbursement rates per patient, including hospital services, daily companion charge rates, professional services and respiratory physical therapy were identified and analyzed for hospitalization cost estimation on a per patient basis.

\section{Data analysis}

A descriptive analysis of demographic and clinical profiles of pneumonia cases was performed. In each costing analysis, mean treatment costs and respective $95 \%$ confidence interval $(95 \% \mathrm{CI})$ and standard deviation (SD) were calculated for severe and very severe pneumonia. Given the low numbers of very severe cases, only severe inpatient cases treated at wards were considered in comparative analysis of costs estimates. The Friedman test was used to investigate cost differences in the methods, via one-to-one comparisons, at a significance level of 0.05. Data were entered into Excel spreadsheets and statistical analyses were performed using the Statistical Package Social Sciences (SPSS) software version 23.

This study was approved by the Ethics Committee of Hospital das Clínicas da Universidade Federal de Goiás, Research Ethics Committee (CEP) protocol MHA/HC/ UFG 174/09.

\section{RESULTS}

\section{Study sample and health resource consumption}

The clinical and demographic features of the 59 CAP inpatients are presented in table 1 . The cases were
Table 1. Clinicoepidemiological features of patients hospitalized with severe and very severe pneumonia

\begin{tabular}{|c|c|c|}
\hline Variables & $\begin{array}{c}\begin{array}{c}\text { Severe pneumonia } \\
(n=52)\end{array} \\
\end{array}$ & $\begin{array}{c}\text { Very severe } \\
\text { pneumonia }(n=7)\end{array}$ \\
\hline \multicolumn{3}{|l|}{ Sex, $n(\%)$} \\
\hline Male & $28(47)$ & $6(10)$ \\
\hline Female & $24(41)$ & $1(2)$ \\
\hline Age (months), mean (SD) & $14.8(9.6)$ & $9(8.3)$ \\
\hline \multicolumn{3}{|c|}{ Criterium to confirm diagnosis, $n(\%)$} \\
\hline Clinical & $26(44)$ & 0 \\
\hline Radiological & $26(44)$ & $7(12)$ \\
\hline Hospital stay (days), mean (SD) & $4(2.2)$ & $7(5.1)^{*}$ \\
\hline \multicolumn{3}{|l|}{ Outcome, n (\%) } \\
\hline Discharge & $52(88)$ & $6(10)$ \\
\hline Death & 0 & $1(2)$ \\
\hline
\end{tabular}

classified according to severity, as follows: 52 (88\%) patients with severe pneumonia, mean length of stay of 4 days (SD: 2.2; minimum, 2 days; maximum, 13 days) and $7(12 \%)$ patients with very severe pneumonia, mean length of stay at ICU and hospital ward of 7 days (SD: 5.1; minimum, 3 days; maximum, 18 days). Hospital stay of patients with very severe pneumonia was significantly $(p<0.0001)$ longer compared to patients with severe pneumonia that did not require admission to ICU.

Health resources and respective amounts utilized for treatment of 52 patients affected with severe pneumonia in this study are detailed in table 2 . All patients received pediatric medical care during admission (mean of 5 medical visits/consultations; SD: 2.1). Only one patient was seen by an infectious disease specialist. Most commonly prescribed antibacterial drugs were ampicillin $(n=42$, mean administration time, 3.14 days; SD: 1.29$)$ and ceftriaxone $(n=15$, mean administration time, 4.8 days; SD: 5.10). Antimicrobial drug combinations were given to 22 patients (ampicillin/ amoxicillin, 17 patients; gentamicin/amoxicillin, 2 patients; ampicillin/amoxicillin/gentamicin, 2 patients; ceftriaxone/oxacillin, 1 patient). Ancillary drugs given were corticosteroids (23 patients), nasal decongestants (30 patients), bronchodilators (21 patients), gastric protectants (10 patients) and antipyretics (40 patients). Laboratory tests and imaging examinations were performed in $16(31 \%)$ and $13(25 \%)$ children, respectively. Three children underwent respiratory physical therapy (mean of 3.67 sessions; SD: 2.08 ) and 49 received nebulization (mean of 3.96 nebulizations/ day; SD: 2.08). 
Table 2. Type and amount of health resource used per hospitalized patients with severe pneumonia

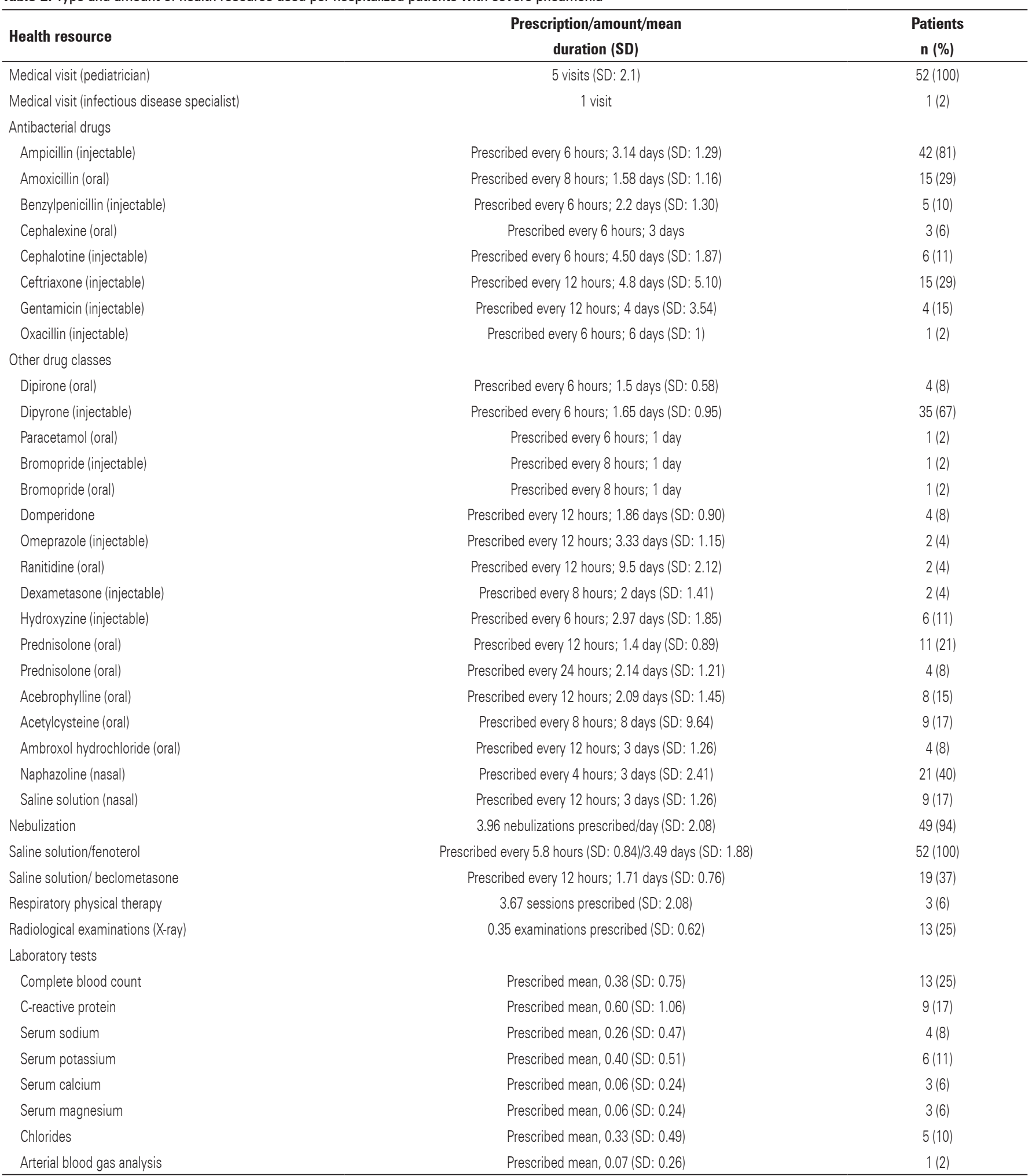

SD: standard deviation.

Costs of pneumonia estimated by different methods Very severe pneumonia treatment costs were significantly $(\mathrm{p}<0.001)$ higher compared to severe pneumonia, regardless of the costing method employed. Severe pneumonia treatment costs varied across costing methods, with mean costs corresponding to $\mathrm{R} \$ 780,70$ 
(medical record review; 95\%CI: 674-885), R\$ 641,90 (therapeutic guideline; 95\%CI: 639-642) and R \$ 594,80 (SUS reimbursement; 95\%CI: 566-627) (Table 3).

Table 3. Inpatient severe and very severe pneumonia treatment Sistema Único de Saúde costs estimated via different costing methods

\begin{tabular}{|c|c|c|c|}
\hline & $\begin{array}{l}\text { Estimated } \\
\text { cost (R\$) }\end{array}$ & $\begin{array}{c}95 \% \text { confidence } \\
\text { interval }\end{array}$ & $\begin{array}{l}\text { Standard } \\
\text { deviation }\end{array}$ \\
\hline \multicolumn{4}{|l|}{ Severe pneumonia $(n=52)$} \\
\hline Costing based on medical record & 780,70 & $674-885$ & 393.50 \\
\hline $\begin{array}{l}\text { Costing based on therapeutic } \\
\text { guidelines }\end{array}$ & 641,90 & $639-642$ & 2.38 \\
\hline Costing based on reimbursement rates & 594,80 & $566-627$ & 108.30 \\
\hline \multicolumn{4}{|l|}{ Very severe pneumonia $(n=7)$} \\
\hline Costing based on medical record & $3.569,20$ & $1,269-5,807$ & 2,453 \\
\hline $\begin{array}{l}\text { Costing based on therapeutic } \\
\text { guidelines }\end{array}$ & $3.369,40$ & $3,263-3,476$ & 8 \\
\hline Costing based on reimbursement rates & $3.175,00$ & $682-5,667$ & 2,719 \\
\hline
\end{tabular}

Based on medical record review, daily cost estimates for the mean length of stay in this study (4 days) amounted to $\mathrm{R} \$ 126,00 / \$$ Int. 138.60 and $\mathrm{R} \$ 19,58 / \$$ Int. 21.53 (hospital ward services and medical fees respectively). Mean overall costs corresponded to $\mathrm{R} \$ 780,70$ (SD: 393.5; minimum, 343.14; maximum, 2,415.96)/\$Int. 858.77, with $\mathrm{R} \$ 750,10 /$ Int. 825) and $\mathrm{R} \$ 30,60 /$ Int. 33.6 reflecting medical and non-medical services respectively. Ward hospitalization costs amounted to $\mathrm{R}$ \$ 507,20 (SD: 269; minimum, 250; maximum, 1,630)/\$Int. 557.90, while drugs costs amounted to $\mathrm{R} \$ 159,00$ (SD: 68, minimum 63.50, maximum 387.30)/ \$Int. 174.90. Antibacterial and ancillary drug costs accounted for $40 \%$ and $60 \%$ (R\$ 64/\$Int. 70.4 and $\mathrm{R} \$ 95 /$ Int. 104.5) of total drug costs respectively.

Therapeutic guideline based costing yielded mean overall cost estimates of $\mathrm{R} \$ 641,90$ (SD: 2.38; minimum, 635.20; maximum, 645)/\$Int. 706, with $\mathrm{R} \$$ 609,90/\$Int. 670.90 and $\mathrm{R} \$ 32,00 / \$$ Int. 35.20 reflecting medical and non-medical costs respectively. Mean values estimated via reimbursement based costing corresponded to $\mathrm{R} \$ 594,80$ (SD: 108.30 ; minimum, 201.07; maximum 847.64)/\$Int. 654.28, with R\$ 565,50/\$Int. 622 and $\mathrm{R} \$ 29,30 / \$$ Int. 32.23 reflecting medical and non-medical costs respectively (Table 4).

Estimated very severe pneumonia treatment costs varied across costing methods. Cost estimates obtained via micro-costing methods (medical record review or therapeutic guidelines) did not differ significantly $(p=0.405)$, while the estimated cost for repayment was significantly lower than the costs estimated by therapeutic guideline $(\mathrm{p}<0.001)$ or medical record review $(\mathrm{p}=0.006)$ basead cost estimates.
Table 4. Treatment cost of severe pneumonia Sistema Único de Saúde per cost component across different costing methods

\begin{tabular}{|c|c|c|c|}
\hline $\begin{array}{l}\text { Severe } \\
\text { pneumonia }\end{array}$ & $\begin{array}{c}\text { Costing } \\
\text { (medical record) } \\
\text { R\$ }(\%)\end{array}$ & $\begin{array}{c}\text { Costing } \\
\text { (therapeutic guidelines) } \\
\mathbf{R} \$(\%)\end{array}$ & $\begin{array}{c}\text { Costing } \\
\text { (reimbursement) } \\
\text { R\$ }(\%)\end{array}$ \\
\hline Hospital services & $507,20(65.0)$ & $504,00(78.5)$ & $487,60(82.0)$ \\
\hline $\begin{array}{l}\text { Professional } \\
\text { services }\end{array}$ & $75,30(9.6)$ & $78,40(12.2)$ & $76,80(12.9)$ \\
\hline Drugs & $159,00(20.4)$ & $18,00(2.8)$ & $\ldots$ \\
\hline $\begin{array}{l}\text { Radiological } \\
\text { examinations }\end{array}$ & $4,30(0.6)$ & $9,50(1.5)$ & $\ldots$ \\
\hline Laboratory tests & $3,30(0.4)$ & $\ldots+--^{\dagger}$ & $\ldots$ \\
\hline Physical therapy & $1,00(0.1)$ & $\ldots+--^{\dagger}$ & $1,10(0.2)$ \\
\hline $\begin{array}{l}\text { Companion } \\
\text { charge rates }\end{array}$ & $30,60(3.9)$ & $32,00(5.0)$ & $29,30(4.9)$ \\
\hline $\begin{array}{l}\text { Final mean cost } \\
\mathrm{R} \$ \text { (\$Int) }\end{array}$ & $780,70(858.65)$ & $641,90(705.00)$ & $594,80(654.40)$ \\
\hline
\end{tabular}

\section{DISCUSSION}

There is evidence to suggest that length of stay has a significant impact on overall hospital costs, ${ }^{(20)}$ including pneumonia or pneumococcal disease treatment. ${ }^{(21,22)}$ Mean length of stay in this study (4 days) is within expected SUS time frame for pneumonia treatment ${ }^{(17)}$ and is consistent with WHO (World Health Organization) recommendations of 5 days, and with data from a recent global systematic review addressing treatment costs of pneumonia in children (mean of 5.8 days). ${ }^{(23)}$

The hospital costs of severe pneumonia in children estimated in this study reflect data from Latin American studies ( $\mathrm{R} \$ 721,36$ to $\mathrm{R} \$ 1.488,26$, top-down gross-costing ${ }^{(24)}$ and up to $\mathrm{R} \$ 1.373,53^{(25)}$ or $\mathrm{R} \$ 2.957,34,{ }^{(26)}$ combined bottom-up/top-down costing) following adjustment for inflation in the country of origin and conversion to American dollars (PPP 2010) $)^{(6)}$ to reals (2011). As expected, costs estimates based on reimbursement rates were significantly lower compared to costs estimates based on medical record review.

Cost-of-illness estimates are vital for economic burden, health status and health intervention costeffectiveness studies. Brazilian studies comparing cost estimates based on SUS reimbursement rates and other inpatient treatment costing methods are scarce. However, evidence suggests that reimbursement rate based costing underestimates true hospitalization costs. ${ }^{(27)}$ Cost estimates based on reimbursement rates differed significantly from estimates based on therapeutic guidelines or medical record review in this study. This finding supports evidence suggesting that costing methods may significantly impact costing studies results. ${ }^{(7,10)}$

Costs estimate differences may reflect different costing methods, method-specific accuracy regarding 
cost component identification in gross-costing or micro-costing, and cost component valuation (top-down or bottom-up approach). ${ }^{(7)}$ Methodological differences may therefore explain cost estimate heterogeneity across Latin American costing studies.

Studies comparing costing methods are scarce. A study by Swindle et al., (28) investigating the value of combined gross-costing and micro-costing to assess variations in utilization of essential hospital resources failed to reveal differences between top-down and bottom-up approaches. Wordsworth et al., ${ }^{(29)}$ compared top-down and bottom-up cost estimates but did not explore the gross-costing method. Tan et al., ${ }^{(20)}$ compared the reliability of overall hospital service cost estimates based on bottom-up/micro-costing, top-down/microcosting or gross-costing analysis in the Netherlands. This study is the first to assess inpatient costs of a single patient sample via three different costing methods.

Bottom-up micro-costing (i.e., costing estimates based on medical record review) is thought to be the most accurate costing method and the gold standard. ${ }^{(7.10)}$ However, this methodology is difficult to apply, labor intensive, time consuming and expensive. The topdown approach combined with micro-costing or grosscosting may represent an easier and less expensive alternative. ${ }^{(7,9)}$ Still, evidence suggests that bottom-up micro-costing is the method of choice to estimate the cost of components with greater impact on overall daily hospital stay costs. ${ }^{(20,29)}$

The hospitalization costs of severe pneumonia patients paid by SUS and estimated via top-down (therapeutic guidelines) or bottom-up (medical record review) micro-costing did not differ significantly in this study, suggesting that top-down micro-costing may be a more practical and less expensive costing alternative. ${ }^{(20)}$ Also, therapeutic guideline based costing is easy to apply within the SUS financing structure and allows cost estimation of a wider range of components compared to reimbursement rate based costing.

This study has several limitations. First, the low number $(n=7)$ of very severe pneumonia cases in the sample limited comparing the three methods in this group of patients. Further costing studies with an adequate number of pneumonia cases requiring ICU hospitalization are therefore warranted. Also, the average daily hospital stay cost of $\mathrm{R} \$ 126,00$ adopted in this study may have translated into increased therapeutic guideline and medical record based cost estimates.

\section{CONCLUSION}

SUS cost estimates obtained via top-down (based on therapeutic guidelines) or bottom-up (based on medical record review) micro-costing did not differ significantly in this study, suggesting that top-down micro-costing may be an alternative to micro-costing based on medical record review for severe pneumonia treatment cost estimation. Studies comparing different costing methods and focusing on different diseases are warranted to support our findings. These results may subsidize economic evaluation of interventions for prevention and control.

\section{ACKNOWLEDGEMENTS}

The authors would like to thank the board of directors and employees of Hospital Infantil de Campinas and Hospital da Criança in Goiânia for technical support, Professor Lee Chenchen from Universidade Federal de Goiás for advice on statistical method selection and Universidade Estadual do Maranhão (UEMA) and Coordination for the Improvement of Higher Education Personnel (CAPES - Coordenação de Aperfeiçoamento de Pessoal de Nivel Superior) for funding this study (joint $\mathrm{PhD}$ grant DINTER/UFG/UEMA).

\section{REFERENCES}

1. Rudan I, O'Brien KL, Nair H, Liu L, Theodoratou E, Oazi S, Lukšić I, Fischer Walker CL, Black RE, Campbell H; Child Health Epidemiology Reference Group (CHERG). Epidemiology and etiology of childhood pneumonia in 2010: estimates of incidence, severe morbidity, mortality, underlying risk factors and causative pathogens for 192 countries. J Glob Health. 2013;3(1):010401.

2. Constenla D, Gomez E, De la Hoz F, O'Loughlin R, Sinha A, Valencia JE, et al. The Burden of Pneumococcal Disease and Cost-Effectiveness of a Pneumococcal Vaccine in Latin America and the Caribbean: a Review of the Evidence and a Preliminary Economic Analysis [Internet]. Washington DC: Vaccine Institute; 2007 [cited 2015 Dec 5]. Available from: www.ispch.cl/ sites/default/files/document1.pdf

3. Andrade AL, Toscano CM, Minamisava R, Costa PS, Andrade JG. Pneumococcal disease manifestation in children before and after vaccination: what's new? Vaccine. 2011;29 Suppl 3:C2-14.

4. Valenzuela MT, O'Loughlin R, De La Hoz F, Gomez E, Constenla D, Sinha $A$, et al. The burden of pneumococcal disease among Latin American and Caribbean children: review of the evidence. Rev Panam Salud Publica. 2009; 25(3):270-9. Review.

5. Rudan I, Boschi-Pinto C, Biloglav Z, Mulholland K, Campbell H. Epidemiology and etiology of childhood pneumonia. Bull World Health Organ. 2008;86(5): 408-16.

6. Bahia L, Toscano CM, Takemoto ML, Araujo DV. Systematic review of pneumococcal disease costs and productivity loss studies in Latin America and the Caribbean. Vaccine. 2013;31 Suppl 3:C33-44. Review.

7. Drummond MF, Sculpher MJ, Torrance GW, O'Brien BJ, Stoddart GL. Methods for the economic evaluation of health care programmes. 3rd ed. USA: Oxford University Press; 2005.

8. Sgambatti $S$, Minamisava R, Bierrenbach AL, Toscano CM, Vieira MA, Policena $\mathrm{G}$, et al. Early impact of 10 -valent pneumococcal conjugate vaccine in childhood pneumonia hospitalizations using primary data from an active population-based surveillance. Vaccine. 2016;34(5):663-70.

9. Mogyorosy Z, Smith P. The main methodological issues in costing health care services: a literature review [Internet]. UK: Centre for Health Economics; 2005 [cited 2017 Apr 6]. Available from: https://www.york.ac.uk/che/pdf/rp7.pdf 
10. Tan SS. Microcosting in economic evaluations: issues of accuracy, feasibility, consistency and generalizability [Internet]. Rotterdam: Optima Grafische Communicatie; 2009 [cited 2017 Apr 6]. Available from: https://repub.eur.nl/ pub/17354

11. Alvis Guzmán N, de la Hoz Restrepo F, Higuera AB, Pastor D, Di Fabio JL. [The economic costs of pneumonia in children under 2 years of age in Colombia]. Rev Panam Salud Publica. 2005;17(3):178-83. Spanish.

12. Lagos R, Muñoz A, Espinoza A, Dowes A, Ruttimann R, Colindres $R$, et al. [Direct medical costs of invasive pneumococcal disease and radiologicallydiagnosed pneumonia among Chilean children]. Rev Panam Salud Publica. 2009;26(2):101-11. Spanish.

13. The World Bank. PPP conversion factor, GDP (LCU per international \$) [Internet]. USA: 2016 [cited 2013 June 1]. Available from: http://data. worldbank.org/indicator/PA.NUS.PPP

14. Brasil. Ministério da Saúde. Banco de Preços em Saúde [Internet]. Brasília (DF): 2011 [citado 2012 Nov 5]. Disponível em: http://bps.saude.gov.br/index.cfm

15. Agência Nacional de Vigilância Sanitária (ANIVISA). Câmara de Regulação do Mercado de Medicamento (CMED). Listas de Preços de Medicamentos [Internet]. 2011 [citado 2012 Nov 5]. Disponível em: http://portal.anvisa.gov. br/listas-de-precos

16. Associação Brasileira do Comércio. Revista ABC Farma [Internet]. 2011 [citado 2012 Nov 5]. Disponível em: http://www.abcfarma.org.br/sobre. asp\#.UJgxPW9G_bE

17. Brasil. Ministério da Saúde. DATASUS. Sistema de Gerenciamento da Tabela de Procedimentos, Medicamentos e OPM do SUS (SIGTAP) [Internet]. Brasília (DF): Ministério da Saúde; 2011 [citado 2012 Nov 5]. Disponível em: http://sigtap.datasus.gov.br/tabela-unificada/app/sec/inicio.jsp

18. Sociedade Brasileira de Pneumologia e Tisiologia; Sociedade Brasileira de Pediatria. Diretrizes Clínicas na Saúde Suplementar. Associação Médica Brasileira. Agencia Nacional de Saúde Suplementar. Pneumonia adquirida na comunidade na infância: diagnóstico e tratamento das complicações [Internet]. São Paulo: Associação Médica Brasileira. Agencia Nacional de Saúde Suplementar; 2011 [citado 2012 Nov 5]. Disponível em: http:// diretrizes.amb.org.br/ans/pneumonia_adquirida_na_comunidade_na infancia-diagnostico_e_tratamento_das_complicacoes.p.pdf
19. Brasil. Ministério da Saúde. Manual Técnico Operacional do Sistema de Gerenciamento da tabela, Procedimentos, Medicamentos e OPM do SUS SIGTAP versão DESKTOP. Volume I. Brasília (DF): Ministério da Saúde; 2011. V. $1.58 \mathrm{p}$.

20. Tan SS, Rutten FF, van Ineveld BM, Redekop WK, Hakkaart-van Roijen L. Comparing methodologies for the cost estimation of hospital services. Eur $\mathrm{J}$ Health Econ. 2009;10(1):39-45.

21. UK Health Protection Agency. Current Epidemiology of Invasive Pneumococcal Disease (IPD) [Internet]. 2011 [cited 2016 Nov 16]. Available from: http:// www.hpa.org.uk/Topics/InfectiousDiseases/InfectionsAZ/Pneumococcal/ Epide

22. Cupurdija V, Lazic Z, Petrovic M, Mojsilovic S, Cekerevac I, Rancic N, et al. Community-acquired pneumonia: economics of inpatient medical care vis-à-vis clinical severity. J Bras Pneumol. 2015;41(1):48-57.

23. Zhang S, Sammon PM, King I, Andrade AL, Toscano CM, Araujo SN, et al. Cost of management of severe pneumonia in young children: systematic analysis. J Glob Health. 2016;6(1):010408.

24. Constenla DO. Economic impact of pneumococcal conjugate vaccination in Brazil, Chile, and Uruguay. Rev Panam Salud Publica. 2008;24(2):101-12.

25. Vespa G, Constenla DO, Pepe C, Safadi MA, Berezin E, de Moraes JC, et al. Estimating the cost-effectiveness of pneumococcal conjugate vaccination in Brazil. Rev Panam Salud Publica. 2009;26(6):518-28.

26. Sinha A, Constenla D, Valencia JE, O'Loughlin R, Gomez E, de la Hoz F, et al. Cost-effectiveness of pneumococcal conjugate vaccination in Latin America and the Caribbean: a regional analysis. Rev Panam Salud Publica. 2008;24(5): 304-13.

27. La Forgia GM, Couttolenc BF. Desempenho hospitalar no Brasil: em busca da excelência. 1a ed. São Paulo: Singular; 2009.

28. Swindle R, Lukas CV, Meyer DA, Barnett PG, Hendricks AM. Cost analysis in the Department of Veterans Affairs: consensus and future directions. Med Care. 1999;37(4 Suppl Va):AS38. Review.

29. Wordsworth S, Ludbrook A, Caskey F, Macleod A. Colecting unit cost data in multicentre studies. Creating comparable methods. Eur J Heal Econ. 2005; 6(1):38-44 